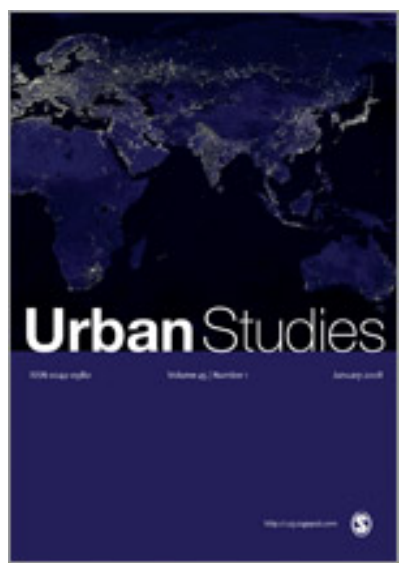

\title{
Housing wealth, mortgages and Australians' labour force participation in later life
}

\begin{tabular}{|c|c|}
\hline Journal: & Urban Studies \\
\hline Manuscript ID & CUS-497-20-05.R2 \\
\hline Manuscript Type: & Special Issue \\
\hline $\begin{array}{l}<\text { b }>\text { Discipline: Please select a } \\
\text { keyword from the following } \\
\text { list that best describes the } \\
\text { discipline used in your paper.: }\end{array}$ & Economics \\
\hline $\begin{array}{l}\text { World Region: Please select } \\
\text { the region(s) that best reflect } \\
\text { the focus of your paper. } \\
\text { Names of individual countries, } \\
\text { cities \& economic groupings } \\
\text { should appear in the title } \\
\text { where appropriate.: }\end{array}$ & Australia \\
\hline $\begin{array}{r}\text { Major Topic: Please identify } \\
\text { up to } 5 \text { topics that best } \\
\text { identify the subject of your } \\
\text { article.: }\end{array}$ & Housing, Demographics, Employment/Labour \\
\hline $\begin{array}{r}\text { You may add up to } 2 \text { further } \\
\text { relevant keywords of your } \\
\text { choosing below: }\end{array}$ & Housing wealth, Mortgage debt \\
\hline
\end{tabular}

\section{SCHOLARONE \\ Manuscripts}




\title{
HOUSING WEALTH, MORTGAGES AND AUSTRALIANS' LABOUR FORCE PARTICIPATION IN LATER LIFE
}

\begin{abstract}
In the life cycle model of consumption and saving homeownership is an important vehicle for horizontal redistribution. Households accumulate wealth in owner-occupied housing during working lives before benefiting from imputed rent streams in retirement. But in some countries housing wealth's welfare role has broadened as owners increasingly use flexible mortgages to smooth consumption during working lives. One consequence is higher outstanding mortgages later in life, a burden exacerbated by high real house prices that compel home buyers to demand mortgages that are a growing multiple of their incomes. We investigate whether these developments are prompting longer working lives, an idea that is especially relevant in countries offering relatively low government pensions. Australia is one such country. We use the 2001-2017 panels of the Household, Income and Labour Dynamics in Australia Survey to estimate hazard models of exits from the Australian labour force as workers approach pensionable age. We find those with high outstanding mortgage debts are more likely to postpone retirement, as are those with relatively low amounts of private pension wealth. These results are stronger in urban housing markets, and especially among males.
\end{abstract}

\section{Keywords}

housing wealth, mortgage debt, mature age, labour force participation, Australians

\section{Introduction}

In countries such as Australia, where state pensions are means-tested and benefits are low by international standards (OECD, 2017), the wealth that owners accumulate in their homes plays a vital role as a vehicle for horizontal redistribution across the life 
cycle. The housing wealth that homeowners accumulate during working lives, can be thought of as a pension that can help support wellbeing in old age, especially those with low pension benefits who are especially prone to after-housing cost poverty. It can do this in at least two ways - as a hedge against rising rents, and as a store of wealth that can be released to buffer shocks. Elderly outright owners with low government age pensions as their primary source of income are then less likely to experience poverty in old age (Yates and Bradbury, 2010; Ritakallio, 2003).

These ideas have been central to asset-based welfare strategies whereby "individuals are encouraged to accept more responsibility for satisfying their own welfare needs by investing in financial products and assets that are expected to increase in value and be drawn upon in times of need" (Dewilde \& Ronald, 2017) ${ }^{1}$. In countries like Australia and the UK, asset-based welfare systems are replacing traditional welfare systems as epitomised by the homeownership - pension trade-off that has been identified in numerous empirical studies (see, for example, Doling and Horsewood, 2003; 2005; 2011; Delfani et al., 2014).

But homeownership's role as a vehicle for horizontal redistribution has weakened as owners increasingly use flexible mortgages to roll out housing equity to smooth consumption during working lives, especially in the child rearing stages of the life course (Lowe, 2011; Wood et al., 2013). One consequence is higher outstanding mortgages later in life, a burden exacerbated by rising real house prices that require first home buyers and owners trading up into higher value segments to take on mortgages

\footnotetext{
1 The theory of 'asset-based welfare' was originally described by Sherraden (1991) in the context of using savings and assets-building to alleviate poverty.
} 
that are a growing multiple of their incomes. Australian Bureau of Statistics (ABS)

Surveys of Income and Housing confirm these propositions; they show that the share of mortgagors among owners aged 45-54 years has more than doubled from 36 percent in 1990 , to 77 percent in 2015 . There are even steeper increases among owners aged 55-64 years; their mortgagor share has more than tripled from 14 percent in 1990, to 47 percent in 2015. For homeowners nearing the end of their working lives, risky mortgage practices alongside house price volatility can seriously undermine the security afforded to them through homeownership (Arundel \& Ronald, 2021) This is especially the case for older homeowners with growing mortgage debt for whom loss of homeownership is a serious risk (see Ong et al., 2015).

Unexpectedly high mortgage debt burdens may prompt longer working lives to meet mortgage repayments and build housing (net) wealth that can be used to buffer adverse shocks in old age. Then again, owners improving longevity may encourage longer work careers and a willingness to carry greater mortgage debt and lower accumulations of housing wealth into later years. Whatever the causal mechanism, a housing wealth retirement trade-off could then mediate or even replace the homeownership pension trade-off that has been at the heart of the asset-based welfare literature (Doling and Horsewood, 2003; 2005) ${ }^{2}$, and in ways similar to intrafamilial transfers role in

\footnotetext{
2 The original trade-off hypothesis as outlined in Kemeny (2005) predicts that societies with low government retirement pensions, and poor public welfare provision for the elderly, compel households to make private provision for their old age through outright ownership of their housing achieved at an early stage of their life course. The housing wealth retirement trade off suggests that labour force participants are instead compelled to remain active in labour markets later in their lives (Doling and Horsewood, 2005), as outright ownership is unachievable before pensionable age, and/or households tap into their housing equity meet welfare needs during their working lives.
} 
moderating the ownership-age pension trade-off in Southern Europe (Castles \& Ferrera, 1996).

These ideas motivate our empirical investigation into the timing of retirements. Australia offers an interesting context. The country traditionally relied on a wage earners welfare system (Castles, 1997) based on arbitration institutions that policed high minimum wages, migration barriers that restricted labour supply, regulation of the private sector to deliver social insurance benefits normally delivered through social security (Herscovitch and Stanton, 2008) and buttressed by tariffs that encouraged employer compliance (Lloyd, 2017). Since the 1980s this wage earners welfare system has been dismantled and replaced by an increasingly asset-based welfare strategy for old age. So, Australia is an early adopter of this approach (Castles, 2001; Yates and Bradbury, 2010). Households are encouraged by generous subsidies to store wealth in housing and compelled to accumulate savings in mandatory occupational pension accounts. Meanwhile government age pensions continue to be set at low levels by international standards, and income support payments are tightly targeted on those with low incomes. The ways in which Australians' retirement decisions have changed in such an environment might then be a portent of what is to come in other homeownership societies that pivot toward asset-based welfare strategies. These developments are emerging in one of the most highly urbanised nations in the world, and where high urban house prices are concentrating personal wealth in housing assets 
(Kohler and Smith, 2005). Home ownership retirement links could then be particularly strong in Australia. ${ }^{3}$

\section{Literature review}

The relevant international literature straddles the fields of economics, industrial relations, organisational behaviour and sociology. Most studies utilise microdata and econometric modelling methods appropriate when using a binary choice dependent variable on employment, or retirement status (Mann, 2011; Skučiene and Moskvina, 2015; Begley and Chan, 2018). However, three other approaches deserve attention. First, a few studies opt for model specifications that allow analyses of more than two outcomes. Bloemen (2016) estimates a multinomial logit to model three outcomes staying employed, retirement and involuntary job exit. Warren (2015) utilised multinomial logits to model seven retirement pathways. A second group of studies adopt a difference-in-difference approach (Disney and Gathergood, 2018). Finally, there are papers reporting hazard model estimates of the conditional probability of exiting employment in later life. Ondrich and Favelich (2016) apply hazard modelling to binary outcomes; Roy (2018) runs a competing risk hazard model of five possible routes out of employment.

We find three key themes in this literature; the first concerns the importance of organisational and work-related factors on decisions to retire (see Chen et al's (2019)

\footnotetext{
3 The urban population makes up 86 percent of total population in Australia, compared to an OECD average of 81 percent, and a world average of 56 percent. See https://data.worldbank.org/topic/urbandevelopment?locations $=$ AU-OE-1W-EU.
} 
systematic review). Key drivers include lack of autonomy (Skučiene and Moskvina, 2015), physical job demands (Berglund et al., 2017), lack of training, commuting time (Chapela, 2012), illness (Chapela, 2012) and poor working conditions (Livanos and Imanol, 2017). Secondly, financial need is typically positively correlated with extended working lives (Livanos and Imanol, 2017). Thirdly, there is a body of literature highlighting social security benefits role in incentivizing early retirement, particularly among men (Gruber and Wise, 1998; Marmora, 2015), and more broadly on the employment outcomes of those on low-incomes or housing assistance (Feeny et al., 2010; Beer et al., 2015). Unsurprisingly, the literature confirms health conditions as a key driver of older persons' labour force exits (Toughill et al., 1993; Roy, 2018).

That small literature examining relationships between housing wealth, mortgage debt and mature age labour force participation (LFP) is relatively recent. It finds positive links between home equity gains and early retirement. Atalay et al. (2016) used the Household, Income and Labour Dynamics in Australia (HILDA) Survey to investigate relationships between Australian house prices, household debt and labour supply. On estimating fixed effects models of labour supply, they found that older female homeowners were more likely to retire early in response to above-average house price gains. US and European studies have reached the same conclusion (Bloemen, 2011; Disney and Gathergood, 2018; Zhao, 2018). However, Ondrich and Falevich (2016) discovered that increases in housing equity lift married men's chances of early retirement, Begley and Chan (2018) showed that older males exposed to negative housing price shocks were less likely to retire, and Doling and Horsewood (2003) found that countries with higher homeownership rates have lower LFP rates among older males. Another key result is mortgage debt's positive links with LFP. Atalay et al. 
(2016), Ondrich and Falevich (2016) and Bloemen (2011) and Mann (2011) all found that higher mortgage debt values prolonged working lives.

We conclude this literature review by highlighting research gaps which we seek to fill. First, few papers report separate estimates of house price (or housing equity) and mortgage debt impacts on LFP rates, and only Atalay et al. (2016) draws on Australian data. We contribute a new Australian analysis on the relative impacts of house values and mortgage debt over a long timeframe 2001-2017.

Second, house prices and household mortgage debt are higher in large Australian cities than in non-metropolitan Australia. Indeed, households in urban areas also hold a relatively high proportion of their assets in their own home (Kohler and Smith, 2005). Housing equity and mortgage debt will likely play a more important role in shaping the retirement decisions of urban households. We stratify our data into urban and regional subsamples to detect any differential effects by location.

Third, our paper is one of the first to estimate a competing risk model of alternative pathways out of the labour force, which has an added advantage in that it addresses right censoring problems bedevilling analysis of labour force transitions ${ }^{4}$. The pathways we explore are novel; a distinction is drawn between enduring exits from the labour force and those exiting but retaining a marginal attachment to the labour force. The latter have not entirely cut their ties and may re-enter the labour force if opportunities arise.

Fourth, our empirics distinguish between the silent generation born before 1946 and baby boomers born 1946-1965. Baby boomers exhibit some distinctive features which

\footnotetext{
${ }^{4}$ See Singer and Willett (2003, pp. 587-595).
} 
may affect LFP decisions. These include a greater willingness to drawdown housing equity to fund retirement and higher expected retirement living standards (Warren, 2015). Younger baby boomers have also been exposed to the Australian pivot toward an asset welfare-based strategy for much more of their working lives.

\section{Method}

\subsection{Persons sample}

We draw on the 2001-2017 HILDA Survey, an Australian nationally representative longitudinal dataset offering an abundant reserve of household- and individual-level information. Of particular relevance is individuals' demographic profiles, labour market outcomes, residential locations as well as their housing wealth, non-housing assets and debt. HILDA offers one of the best datasets for studying the dynamics of wealth accumulation and impacts on retirement. It is capable of profiling the equity an owneroccupier accumulates in their home and their outstanding mortgage debt on an annual and uninterrupted basis 2001-2017, and for a sample representative of the Australian adult population (Watson and Wooden, 2021). HILDA therefore has an advantage as compared to both the US Panel Survey of Income Dynamics and its Retirement and Savings Survey, which are biannual. The British Household Panel Survey has the disadvantage of interruption and discontinuity during our study timeframe when replaced by the larger Understanding Society. HILDA also has low rates of attrition by international standards (Watson et al., 2019), and observes internationally recognised panel maintenance standards (Watson, et. al., 2019). 
A multi-stage sampling approach is followed. First, we select adults observed in every wave of the survey from 2001 until $2017^{5}$. Second, we retain persons if they are aged 50-60 years old and a labour force participant at some point between 2001 and 2017. The sample design therefore offers a rolling snapshot of mature age labour force participants as they approach pensionable age and beyond. In these life cycle segments LFP decisions are inevitably linked with wealth and debt positions (see for instance, Doling and Horsewood, 2003).

Third, housing wealth and mortgage debt variables are reported on a household basis which can be problematic in the case of unrelated persons living in group or multifamily households. We exclude such persons from the analysis. They are a small minority, so their omission is unlikely to affect conclusions ${ }^{6}$.

Fourth, we include LFPs with only one uninterrupted spell over the 2001-2017 window. Of the 2166 persons retained in stages $1-3$ of the sample design $519(24 \%)$ churned in and out of the labour force on one or more occasions, and thus their departures proved temporary. After omitting these churners, the final sample comprises 1647 single spell individuals.

We include owners and renters in the sample. Renters' measures of housing wealth and mortgage debt are zero in model specifications. We expect more robust findings on embracing those choosing or constrained to hold no housing equity or secured debt in sample designs.

\footnotetext{
5 Those dying before 2017 are retained, provided they participated in every wave prior to their year of passing and labour force status is observed from 2001 through to death.

${ }^{6}$ Approximately 2.5 percent of the sample formed at stage 1 of the sample design.
} 


\subsection{Labour force spells, hazard rates and survival rates}

For the ongoing spells in the labour force (that is employed or unemployed ${ }^{7}$ of persons that reached the 50 years of age threshold in 2001 or earlier, spells begin in the first wave of the panel dataset (2001). The spells of those turning 50 years old post-2001 start in the year they reached 50 years of age, or if out of the labour force at that time, the year their next spell in the labour force begins.

Those not in the labour force (NILF) comprise two groups. The ABS (ABS, 2018) define the marginally attached as individuals that (i) want to work, are actively seeking work but not available to start work, or (ii) they want to work and are available to start work within four weeks, but are not actively looking for work. This definition is in line with the International Labour Organisation's international guidelines (Hussmanns et al., 1990). The other NILF group are enduring exits because they (i) do not want to work or (ii) want to work but are neither actively seeking work nor available to start work within four weeks.

Labour force participants in any given year of their spells are 'at risk' of exiting the labour force. On exiting the labour force, persons experience a 'target event' and drop out of the risk set. Spells ongoing in 2017, the final year of the observation 'window', or prematurely ended by death, are right 'censored'. The ultimate outcomes are unknown because their status is not observed beyond the year when spells are censored. Two key measures can be estimated. The hazard rate is defined as the proportion of individuals

\footnotetext{
7 Those without work are unemployed if they satisfy three criteria - they (i) want to work, (ii) are actively seeking work and (iii) currently available for work (ABS 2018).
} 
exiting the labour force in any given year $(t=2,3 \ldots 17)$, conditional on their labour force presence in the previous year. We also report the survival rate which is the probability of a randomly selected individual's continued presence in the labour force past year $t$.

\subsection{Models}

We estimate discrete-time and competing risk models. The hazard rate $(h)$ for individual $i$ in discrete-time period $j$ is the probability that $\mathrm{s} /$ he will exit the labour force $(T)$ in time period $j$ conditional on the event $\mathrm{T}$ not having occurred before time period $j$, and his/her values for the $P$ predictors in time period $j$. Letting $X_{1 i j,} X_{2 i j \ldots .} X_{\mathrm{P} i j}$ represent the $\mathrm{P}$ predictors and $x_{\mathrm{P} i j}$ denote individual $i$ 's values for the $p^{\text {th }}$ predictor in time period $j$ we can write the hazard function as:

$h\left(t_{i j}\right)=\operatorname{Pr}\left[T_{i}=j \mid \mathrm{T}_{\mathrm{i}} \square j\right.$ and $\left.X_{1 i j}=x_{1 i j}, X_{2 i j}=x_{2 i j}, \ldots, X_{\mathrm{P} i j}=x_{\mathrm{Pi} j}\right]$

The standard approach expresses hazard as the logarithm of the odds of event occurrence, that is on a logit scale, and fits the discrete-time hazard model to the data by maximum likelihood using a logistic regression routine ${ }^{8}$. Logit hazard is specified as a function of $j=17$ time indicators and $p$ predictors. We can express the discrete-time hazard model as:

logit $h(t)=\left[\alpha_{1} D_{1}+\alpha_{2} D_{2}+\ldots \ldots . .+\alpha_{17} D_{17}\right]+\left[\beta_{1} X_{1}+\beta_{2} X_{2}+\ldots \ldots . .+\beta_{P} X_{P}\right]$

where for simplicity we have dropped the subscripts $i$ and $j$. The alphas represent the baseline logit hazard function that evolves as time since the beginning of a spell

\footnotetext{
8 The likelihood function is specified in such a way as to appropriately include the contribution of censored and non-censored individuals. See Willet and Singer (2003, pp. 381-384).
} 
unfolds, and given zero values for each predictor. The beta's shift the baseline function holding constant all other predictors. The antilog of a beta estimate yields the estimated odds ratio for a one-unit difference in the predictor variable. An estimated odds ratio greater (less) than one indicates that the odds of event occurrence (transitions out of the labour force) are higher (lower) for a one-unit difference in the predictor.

We begin by examining the hazard regardless of the type of exit. Logit hazard models are estimated for samples drawn from all spells, those spells belonging to individuals in urban and non-urban locations (as determined at the start of their spell), as well as stratified models representing different birth cohorts and gender. Estimation of stratified logit hazard models across sub-samples are sensitivity tests exploring differences in retirement decisions attributable to higher house prices and debt in urban locations, as well as birth cohort and gender specific divergent preferences toward savings and consumption.

Marginally attached exits and enduring exits 'compete' to end individuals' labour force spells and the distributions of risk may differ across these two events. An approach allowing these distributions to differ estimates the event-specific hazard rate by acknowledging how an individual can leave the risk set, not just due to the target event, or censoring, but also by experiencing the competing event.

In a competing risk model of enduring transitions the censoring indicator is redefined to include everyone who did not experience a labour force exit by the end of the observation window (fully censored), plus those retaining a marginal attachment despite exiting before the observation window 'closes' (the event censored). This is estimated across the full spell sample, as is the competing risk model of exiting the labour force 
with marginal attachment. The censoring indicator once more includes the fully censored, but now the event censored are enduring transitions out of the labour force before the observation window 'closes'.

\subsection{Predictors}

There are two key predictors - housing wealth and mortgage debt secured against the primary home. Housing wealth is observed from annual self-reported primary home values, tenants being assigned zero values. For couples, each partner is allotted 100 percent of the household's housing wealth on the assumption that homes are an indivisible asset and therefore both partners have joint claims. If one partner dies, the widow(er) is typically bequeathed the entire housing equity.

Mortgage debt is the annual self-reported debt secured against the primary home. Total outstanding debt is again assigned to each partner assuming both partners have joint and full liability. While unexpectedly large mortgages can compel mortgagors to defer labour force exits, reverse causation is possible. Those planning to retire later in life are more inclined to carry a larger mortgage debt to bring forward consumption plans. The potential endogeneity bias is addressed by including the age of intended retirement as a predictor in the model. The strategy aims to isolate the impact of unanticipated delays in paying off mortgage debt on the timing of departures from the labour force, controlling for the work-leisure-consumption preferences shaping retirement plans. Time-varying predictors, including wealth and debt values, are lagged one year to further address reverse causality concerns.

Non-primary home wealth and debt variables are also likely to influence LFP decisions. Most obvious is pension wealth and other property assets while debt includes personal 
loans and credit card balances. In addition, housing tenure is relevant because homeowners' housing outlays typically decline as mortgages are paid off, but tenants rents normally rise over time, compelling tenants to be cautious about retirement decisions.

Key socio-demographic controls include birth cohort, marital status, long-term health condition, and informal carer responsibilities. Birth cohorts can uncover generational differences in attitudes towards LFP and differential exposure to a post-1970s asset welfare based strategy. A long-term health condition may discourage continued employment, and carer responsibilities can prompt early exits.

Human capital and employment characteristics will help drive LFP decisions. Those with superior qualifications have higher permanent incomes, though the direction of any effect is unclear a priori. Unemployment and precarious employment are likely precursors of mature age labour force exits. A labourer indicator is entered as physically demanding work is increasingly difficult to fulfil as we age.

Two variables measure an individual's financial situation while out of the labour force; both affect incentives to remain in work. The replacement rate (RR) is defined as the ratio of each individual's household disposable income while NILF, to household disposable income while in the labour force. High RRs blunt incentives to remain in work. The denominator is observed during spells in the labour force. However, the numerator is unobservable and imputed by estimating a linear regression model of (logged) household income on a sample of all persons NILF, and using the model's estimated coefficients to predict NILF household incomes for labour force participants. Spikes in transitions out of the labour force on becoming eligible for the government 
age pension are detected by a binary indicator that equals 1 in the year a person becomes eligible, zero otherwise.

Geographical variation in housing prices and rents is captured by spatial variables ranging from major cities to remote areas. Macroeconomic conditions have fluctuated over a turbulent period and are captured by indicators marking the pre-GFC era, the GFC years, and post-GFC recovery ${ }^{9}$

\subsection{Instrumenting self-reported primary home values}

Self-reported primary home values are prone to measurement errors that bias the estimated coefficient on housing wealth variables in hazard models. We address this issue by re-estimating the discrete-time hazard models using an instrumental variable (IV) approach to measurement error. The instrument is real median property price for the suburb in which an owner resides and is drawn from house and unit transactions data provided by the Australian Property Monitors data. The median price is that of houses (units) sold in the most recent financial year. For instance, the 2017 median house price is obtained from house sales made between July 2016 and June 2017. Median property prices are converted into 2017 values. Suburbs are represented by Statistical Areas Level 2 (SA2's), areas designed to represent commonly recognised communities. There are over 2,300 SA2's with an average population of around 10,000 persons (ABS 2016).

Because our hazard models are non-linear, the IV approach is executed within a twostage residual inclusion (2SRI) estimation framework (Terza et al. 2008), instead of the

\footnotetext{
${ }^{9}$ Further details on the explanatory variables can be found in a separate supplementary materials section, which can be found alongside the full-text online.
} 
two-stage least squares framework applied to linear models. In the first stage, selfreported real property prices are modelled as a linear function of the matched (by year and suburb) instrument as well as other controls. The instrument is highly correlated with self-reported real property prices. The stage 1 modelling results indicate that, ceteris paribus, every A $\$ 10,000$ increase in the real median suburb price is associated with a $A \$ 25,900$ higher real self-reported property price, indicating that households estimate changes in their property's value that are 2.6 times that typical in their suburb. This association is highly significant at the 1 percent level ${ }^{10}$.

Residuals equal to the actual self-reported prices minus the predicted prices from the first stage regression are calculated. In the second stage of the 2SRI estimation framework the self-reported prices and residuals are entered into the discrete-time hazard model along with the other relevant explanatory variables. The self-reported prices and residuals are again lagged one year.

\section{Key findings}

\subsection{Labour force participation trends and mortgagor status}

Figure 1 uses cross-section population weights to profile Australian homeowners' LFP rates and their mortgage indebtedness in the 50-60 years age group from 2001 to 2017. The cross-sectional snapshots show that mature age homeowners' LFP rates rose by 10 percentage points, from 70 to 80 percent. The growing labour market activity of mature age owners is matched by a surge in their mortgage indebtedness. Only a little over 1 in

\footnotetext{
10 The full stage 1 model results are available from the authors upon request.
} 
4 were still paying down mortgages back in 2001; but by 2017 it exceeded 1 in 2 . In only 16 years indebtedness among mature age owners was transformed from one where mortgages were a continuing burden for a minority, into one that burdens the majority. This transformation is marked by a strong positive correlation between the share of mortgagors among owners and LFP rates. To the extent that rising indebtedness is eating into the housing equity of mature age owners, these patterns are consistent with a housing wealth-retirement trade-off.

\section{[Figure 1 here]}

\subsection{Longitudinal analysis of the drivers of LFP among mature age Australians}

Table 1 widens the sample frame by adding tenants and analyses the duration of spells in the labour force drawn from the balanced panel of mature age survey participants described in section 3. Because life is finite the target event, transition out of the labour force, is inevitable and so hazard rates eventually exhibit positive duration dependence. As older Australians' LFP spells unfold, trend increases in hazard rates set in quite quickly, becoming evident from year 8 of a spell onwards. From year 13, hazard rates climb quite steeply and when the time metric reaches $15-17$ years, the hazard rate is invariably over 20 percent. By this stage of their labour market careers most have reached the age pension eligibility threshold, and so a sharply weaker labour force attachment is unsurprising. However, these hazard rates do indicate that most of this cohort of mature age Australians work for 10 years or more from the time we first start tracking them.

\section{[Table 1 here]}


Using the same spells sample, table 2 reports findings from estimation of discrete time hazard models. Two sets of results are presented; coefficient estimates in column 2 are from our discrete time hazard model as specified in equation 1. In column 3 we list results from the second stage of the 2SRI estimation framework.

Both models deliver very similar findings. Higher levels of mortgage debt secured against the primary home are associated with longer working lives. Every A $\$ 10,000$ increase in real primary home mortgage debt reduces the odds of exiting the labour force by between 8 and 9 percent, although both estimates are only weakly significant ${ }^{11}$. Curiously, primary home value parameter estimates are statistically insignificant. It seems that a fall in primary home equity might only delay labour force exits if it results from higher debt rather than lower home values. This is not as surprising as it might first seem; a house price decline can be reversed when market conditions improve, and regardless of owner behaviour. In contrast, higher debt is locked in if owners do not increase repayments or are compelled to make additional equity withdrawals. These findings also help to make sense of the strong correlation between growing mortgage indebtedness and increasing LFP rates documented in figure 1.

The only other component of household balance sheets that impact transition decisions is occupational pensions (superannuation). Every A $\$ 10,000$ increase in superannuation wealth raises the odds of exiting the labour force by over 3.0 percent in both models, a

${ }^{11}$ When the second stage of the 2SRI model is re-run with clustered standard errors and bootstrapped with 20 replications, the mortgage debt variable remains significant at the 10 percent level. However, the mortgage debt variable gradually loses significance as the number of replications increases. 
smaller impact than that obtained for mortgage debt, but it is a more reliable estimate as gauged by their statistical significance.

Unsurprisingly, years till intended retirement is strongly linked with the timing of actual decisions to exit the labour force. The odds of exiting the labour force rise by over 10 percent in both models for every one-year reduction in years to intended retirement. Birth cohort differences are also apparent in both models even after controls for stage in the life cycle (through years to intended retirement). Those born during WWII are nearly 2.5 times as likely as younger boomers to leave the labour force. Younger boomers could have higher expected standards of living in retirement and are therefore more willing to delay retirement to accumulate sufficient resources to support retirement. .

Other characteristics are also relevant. Ill-health is a very important catalyst triggering moves out of the labour force. Superior qualifications, full-time and secure employment are all associated with delayed transitions out of the labour force. Unemployment is easily the biggest trigger for labour force exits; unemployed mature age Australians are between 12 and 13 times as likely to leave the labour force as the full-time employed ${ }^{12}$. The incentive to work is important; every one percentage point increase in the RR raises the odds of leaving the labour force by around 0.5-0.6 percent. Finally, exits from the labour force household occur later in life during and after the GFC. Slower household income growth and stagnant house prices during the GFC may have prompted more cautious retirement plans among older Australians.

12 Conditional on LFP in wave $t, 3.8$ percent exit the labour force in wave $t+1$, but if unemployed in wave $t$ the exit rate is 20.7 percent. 


\section{[Table 2 here]}

\subsection{Do the relationships between housing wealth, mortgage debt and labour force participation vary by geography, birth cohort and sex?}

Next, we report estimates from the models stratified by urban versus non-urban locations, birth cohorts 1941-45, 1945-55 and 1956 onwards, and men versus women. Because 2SRI estimates produced similar findings in table 2, we only report discrete hazard model results for the stratified samples. Results for selected predictors of interest are reported in table 3.

Consider first the estimates in the upper panel table $3 \mathrm{a}$ with all predictors in the model. The urban versus regional stratification confirms expectations of a larger mortgage debt effect in urban housing markets. Every $\mathrm{A} \$ 10,000$ increase in mortgage debt depresses the odds of leaving the labour force by 11.5 percent.

In gender stratified samples the mortgage debt effect is only detected among males where every $\mathrm{A} \$ 10,000$ rise in mortgage debt reduces the odds of exit by 12.2 percent. Gender wage and participation rate gaps could be responsible since males are typically the main source of wage income in couple households; their prolonged LFP is then more important to the pay down of mortgages. In contrast superannuation effects are only apparent among females; $\mathrm{A} \$ 10,000$ increments in superannuation balances lift the odds of exit by 4.7 percent. Female work careers are more often interrupted by child rearing responsibilities that translate into lower superannuation balances (Jefferson and Preston, 2005). Furthermore, divorced women are more likely to acquire the family home in asset divisions following break ups (Mikolai and Kulu, 2018). An incremental 
improvement in females' superannuation is then likely to impact more strongly on the duration of LFP spells.

The mortgage debt effect disappears in models stratified by birth cohorts. However, larger superannuation balances are found to hasten exits from the labour force in all birth cohorts, though only at a 5 percent or better level of significance among the 'war baby' cohort. Future retirement plans are more statistically significant and in all birth cohorts. Indeed, this variable is to the forefront in all stratified models. It could be responsible for weak mortgage debt and superannuation findings. Those that planned to postpone retirement may choose to take on larger mortgage debts ${ }^{13}$, while those that planned early retirement strive to accumulate larger superannuation balances.

In the lower panel table $3 \mathrm{~b}$ we explore further by estimating the stratified models omitting the years to intended retirement variable. Larger mortgage debts now always have larger impacts in terms of delaying exits from the labour force, and statistical significance levels improve, especially in the urban, male and older baby boomer subsamples. Superannuation balances also have a larger impact in terms of accelerating exit from the labour force, and again statistical significance improves.

\section{[Table 3 here]}

\subsection{Enduring exits versus exits with marginal attachment to the labour force}

In table 4, competing risk model estimates are reported. Wealth and debt variables are generally irrelevant for those retaining a marginal attachment on leaving the labour

\footnotetext{
${ }^{13}$ Median mortgage debt among homeowners in the highest quintile as arranged according to years to intended retirement is $\$ 90,000$. It is zero in the lowest quintile.
} 
force. This group are very likely to have been unemployed or on casual contracts in the year preceding exit, and to also have a long-term health condition. Their asset holdings are then less relevant because they are not yet ready to give up work, and in any case, they typically have low property and non-property wealth.

On turning to enduring exits, a somewhat different picture emerges. In the all spells sample, it turns out that primary home debt, superannuation wealth and other property wealth effects are quantitatively important, and in the expected direction, but only superannuation wealth is strongly statistically significant (at 5 percent). Birth cohort effects are now only visible in the case of long-lasting exits, as are qualifications, work incentives and the GFC indicator variables.

Time till intended retirement continues to be strongly correlated with actual transitions out of the labour force, and this is uniform across both transition pathways, though stronger for transitions that sever all attachments to the labour market. On the other hand, while unemployment status remains very important it is less so for those making enduring exits.

In summary, it would appear that enduring transitions out of the labour force are more strongly associated with mature age individuals that have achieved economic independence, as signalled by stronger net wealth positions, and life style preferences, as reflected in earlier intentions to retire. On the other hand, those who leave the labour force while retaining a marginal attachment are in a much more financially precarious position. For instance, long-term health condition is more common among those who retain a marginal attachment (27.3 percent) than those who make enduring exits (23.9 percent). While unemployment was observed in 1.1 percent of waves preceding 
enduring exits, it was observed in 4.3 percent of waves preceding exits with a marginal attachment. Average superannuation wealth is roughly A $\$ 150 \mathrm{k}$ among those who exit with a marginal attachment, but $\mathrm{A} \$ 180 \mathrm{k}$ among those who make enduring exits.

\section{[Table 4 here]}

\section{Conclusion}

This paper draws on Australian data to analyse how housing wealth and mortgage debt affect the timing of exits from the labour market among older home owners. Australia is a highly urbanised nation that has pivoted in the direction of an asset-based welfare strategy for support in old age. The ways in which Australians' retirement decisions change in response to this pivot might signal what is to come in other homeownership societies contemplating asset-based welfare strategies for their elderly.

Our hazard models are estimated using data that extend beyond the pre-GFC years investigated by other studies that have applied similar modelling approaches; we also look beyond standard tenure status indicators to investigate the differential impacts of housing wealth and mortgage debt on retirement timing ${ }^{14}$.

The empirical research finds that higher levels of mortgage debt secured against the primary home have a large impact in prolonging working lives in Australia, but the effect's statistical significance is restricted to urban mortgagors, especially males,

14 Warren (2015) and Roy (2018) draw on 2001-2008 and 1992-2010 data respectively. Furthermore, neither explicitly model housing wealth and mortgage debt values. 
whose indebtedness is relatively high ${ }^{15}$. Among this subgroup of mortgagors every A $\$ 10,000$ increase in mortgage debt secured against the home reduces the odds of exiting the labour force by between 17 and 18 percent ${ }^{16}$. Among other household balance sheet variables, larger superannuation balances are important and found to hasten labour force exits, though it is only significant at a 5 percent or better level among 'war babies'.

While erosion of housing equity due to increases in mortgage debt delay plans to end working lives, our model estimates suggest that declines in the value of homes (that also eat into housing equity) do not affect the timing of mature age labour force exits. This is likely because capital losses and capital gains are a less reliable source of change in housing equity because they are readily reversed during the upswings and downswings of the housing cycle.

There is another important finding relevant to interpretation of the mortgage debt effect. LFPs prior statements about how many years they expect to work before retiring is strongly linked with subsequent decisions to exit the labour force. On omitting this predictor, the mortgage debt effect becomes statistically more significant in the male and older boomer subsamples. It is also large: for example, among males every A \$10,000 increase in mortgage debt secured against the home reduces the odds of exiting the labour force by 18 percent (see table 3$)^{17}$. This is evidence supporting the idea that part of the impact that mortgage debt has on the timing of retirement, is

\footnotetext{
15 The mean and median mortgage debt of urban (regional) males as reported in wave 17 of HILDA was $\$ 195 \mathrm{k}(\$ 130 \mathrm{k})$ and $\$ 65 \mathrm{k}(\$ 0)$ respectively.

16 To get a sense of their importance note that mortgagors mean debt secured against the primary home is $\$ 227 \mathrm{k}$, so a $\$ 10,000$ increment is 4.4 percent of the overall mean.

17 To get a sense of their importance note that mortgagors mean debt secured against the primary home is $\$ 227 \mathrm{k}$, so a $\$ 10,000$ increment is 4.4 percent of the overall mean.
} 
because those planning to retire late in life are more inclined to borrow against their homes. A broader welfare role for housing where owner-occupiers are more prepared to release housing equity by borrowing up against their homes during working lives is fulfilled at the expense of longer working lives.

As growing numbers of mature age Australians are carrying mortgage debt later in life and delaying their retirements, increasing numbers will be working when the risks of adverse life shocks are higher. Serious ill health, for example, is a career threatening hazard with an elevated risk in later life. Marital breakdown and redundancy are shocks that also involve higher risks because it is more difficult to recover from such shocks in later life. These risk exposures are evident regardless of whether the high mortgage debt levels in late-life are planned or not. The mortgage stress that older indebted homeowners could suffer as a result of these hazards is felt more acutely because financial markets do not supply insurance instruments that enable mortgagors to hedge house price declines (Englund, 2010; Swidler and Hollins, 2010).

Debt induced extensions to working lives could also have wider implications. The tradeoff between pensions and homeownership is an idea central to the asset-based welfare strategy. The correlation between mortgage debt in later life and the timing of retirement suggests that this trade-off could be mediated. Lower state age pension benefits may no longer motivate a higher accumulation of wealth in owner-occupied housing. Instead owners respond by extending their working lives and continue to leverage debt against their home to support the wider welfare role that owner-occupied housing occupies in contemporary welfare systems. Furthermore, while higher 
mandatory contributions into pension schemes ${ }^{18}$ may delay achievement of homeownership, they will not necessarily result in lower ownership rates over the life cycle if labour force participants again respond by delaying retirement. As Australia was one of the first countries to increase reliance on an asset-based welfare strategy, the trends in Australia may signal what is to come in other homeownership societies with deregulated mortgage markets.

There is another wider significance to these developments. Most high-income countries are experiencing population ageing that is expected to reduce economy-wide labour force participation rates, with adverse consequences for economic growth (Kim and Dougherty, 2020). There were fears that strong house price appreciation in recent decades could be the source of wealth effects on LFP decisions that will amplify population ageing effects on economic growth ${ }^{19}$. The source of these wealth effects is housing equity's role as a buffer that can accelerate planned departures from the labour force. But owner-occupiers' growing indebtedness as they approach pensionable age may mean that such fears are exaggerated.

\section{Acknowledgements}

This work was supported by the Australian Housing and Urban Research Institute (grant number 53072) and by the Australian Research Council (ARC)'s Discovery Projects

\footnotetext{
18 The Australian Federal Government introduced mandatory contributions into occupational pensions in 1992, a reform similar to that developed earlier in the Netherlands. Mandatory contributions are currently 9.5 percent of earnings, but are scheduled to increase to 12 percent by 2025-26.

${ }^{19}$ In a similar vein, but from a neoclassical economic choice theoretic perspective, Poterba (2000) argues that favourable wealth shocks from house price appreciation have weak links with consumption because they have encouraged substitution of leisure for work effort.
} 
funding scheme (project DP190101461). Rachel Ong is the recipient of an ARC Future Fellowship (project FT200100422) funded by the Australian Government.

This paper uses unit record data from the Household, Income and Labour Dynamics in Australia (HILDA) Survey. The HILDA Project was initiated and is funded by the Australian Government Department of Social Services (DSS) and is managed by the Melbourne Institute of Applied Economic and Social Research (Melbourne Institute). The findings and views reported in this paper, however, are those of the authors and should not be attributed to AHURI, DSS or the Melbourne Institute.

\section{References}

Arundel R and Ronald R (2021) The false promise of homeownership: Homeowner societies in an era of declining access and rising inequality. Urban Studies 58(6): $1120-1140$.

Australian Bureau of Statistics (ABS) (2016) Australian Statistical Geography Standard (ASGS): Volume 1 - Main Structure and Greater Capital City Statistical Areas, July 2016, Cat. No. 1270.0.55.001, Canberra: ABS.

Australian Bureau of Statistics (ABS) (2018) Labour Statistics: Concepts, Sources and Methods, Feb 2018, Cat. No. 6102.0.55.001, Canberra: ABS.

Atalay K, Barrett, G and Edward R (2016) House Prices, Household Debt and Labour Supply in Australia, Final Report No. 266, Australian Housing and Urban Research Institute, Melbourne. 
Beer A, Bentley R, Baker E, et al. (2016) Neoliberalism, economic restructuring and policy change: Precarious housing and precarious employment in Australia. Urban Studies 53(8): 1542-1558.

Begley J and Chan S (2018) The effect of housing wealth shocks on work and retirement decisions. Regional Science and Urban Economics 73(11): 180-195.

Berglund T, Seldén D and Halleröd B (2017), Factors affecting prolonged working life for the older workforce: the Swedish case. Nordic Journal of Working Life Studies 7(1): 19-36.

Bloemen HG (2011) The effect of private wealth on the retirement rate: an empirical analysis. Economica 78(312): 637-655.

Bloemen HG (2016) Private wealth and job exit at older age: a random effects model. Empirical Economics 51(2): 763-807.

Castles FG (1997) The institutional design of the Australian Welfare State. International Social Security Review 50(2): 25-41.

Castles FG and Ferrera M (1996) Home Ownership and the Welfare State: Is Southern Europe Different? South European Society and Politics 1(2): 163-185.

Chapela JG (2012) The Effect of Residential Location on Retirement Age: Theory and Some Evidence on Male Behaviour in the US. Urban Studies 49(10): 21532168.

Chen MK and Gardiner E (2019) Supporting older workers to work: a systematic review. Personnel Review 48(5): 1318-1335. 
Delfani N, Deken JD and Dewilde C (2014) Home-Ownership and Pensions: Negative Correlation, but No Trade-off. Housing Studies 29(5): 657-676.

Dewilde CL and Ronald R (eds) (2017) Housing Wealth and Welfare [New Horizons in Social Policy]. Cheltenham and Northampton, MA: Edward Elgar Publishing.

Disney R and Gathergood J (2018) House prices, wealth effects and labour supply. Economica 85(339): 449-478.

Doling J and Horsewood N (2003) Home ownership and early retirement: European experience in the 1990s. Journal of Housing and the Built Environment 18: 289308.

Doling J and Horsewood N (2005) Housing opportunities and welfare provision: testing causality. Housing, Theory and Society 22(2): 80-83.

Doling J and Horsewood N (2011) Home ownership and pensions: causality and the really big trade-off. Housing, Theory and Society 28(2): 166-182.

Englund P (2010) Trading on house price risk: Index derivatives and home equity insurance. In: Smith SJ and Searle BA (eds) The Blackwell Companion to the Economics of Housing: The Housing Wealth of Nations. Chichester: WileyBlackwell, pp.499-511.

Feeny S, Ong R, Spong H and Wood G (2012) The Impact of Housing Assistance on the Employment Outcomes of Labour Market Programme Participants in Australia. Urban Studies 49(4): 821-844. 
Gruber J and Wise D (1998) Social security and retirement: an international comparison. American Economic Review 88(2): 158-163.

Herscovitch A and D Stanton (2008) History of Social Security in Australia. Family Matters 80: 51-58.

Hussmanns R, Mehran F and Verma V (1990) Surveys of Economically Active Population, Employment, Unemployment and Underemployment: An ILO Manual on Concepts and Methods, International Labour Office, Geneva. Available at: https://www.ilo.org/wcmsp5/groups/public/---dgreports/--stat/documents/publication/wcms_215885.pdf (accessed 1 May 2020).

Jefferson T and Preston A (2005) Australia's other gender wage gap: Baby boomers and compulsory superannuation accounts. Feminist Economics 11(2): 79-100.

Kemeny J (2005) "The really big trade-off" between home ownership and welfare: Castles' evaluation of the 1980 thesis, and a reformulation 25 Years on. Housing, Theory and Society 22(2): 59-75.

Kim J and Dougherty S (eds) (2020) Ageing and Fiscal Challenges across Levels of Government, OECD Fiscal Federalism Studies. Paris: OECD Publishing. https://doi.org/10.1787/2bbfbda8-en.

Kohler M and Smith K (2005) Housing and the Household Wealth Portfolio: The Role of Location, Research Discussion Paper 2005-10, Reserve Bank of Australia.

Livanos I and Imanol N (2017) Early exit or longer stay? The effect of precarious employment on planned age of retirement. Personnel Review 46(8): 1571-1589. 
Leopold T (2018), Gender differences in the consequences of divorce: a study of multiple outcomes. Demography 55(3): 769-797.

Lloyd P (2017) The Evolution of Tariff Protection and Wage Protection in the Late Colonies and Early Federation. Economic Papers: A Journal of Applied Economic and Policy 36(4): $459-475$.

Lowe S (2011) The Housing Debate. Bristol: The Policy Press.

Mann A (2011) The effect of late-life debt use on retirement decisions. Social Science Research 40(6): 1623-1637.

Marmora, P. and Ritter, M. (2015), Unemployment and the retirement decisions of older workers, Journal of Labor Research, 36(3), 274-290.

Mikolai J and Kulu H (2018) Divorce, separation, and housing changes: a multiprocess analysis of longitudinal data from England and Wales. Demography 55: 83-106.

OECD (2017) Pensions at a Glance (Edition 2017), OECD Pensions

Statistics (database). Available at: https://doi.org/10.1787/6709917aen (accessed 11 November 2020).

Ondrich J and Falevich A (2016) The great recession, housing wealth, and the retirement decisions of older workers. Public Finance Review 44(1): 109-131.

Ong R, Wood G and Colic-Peisker V (2015) Housing older Australians: Loss of homeownership and pathways into housing assistance. Urban Studies 52(16): 2979-3000 
Ritakallio V-M (2003) The importance of housing costs in cross-national comparisons of welfare (state) outcomes. International Social Security Review 56(2): 81-101.

Roy SB (2018) Effect of health on retirement of older Americans: A competing risks study. Journal of Labor Research 39(1): 56-98.

Sherraden M (1991) Assets and the Poor: A New American Welfare Policy. Armonk, NY: M.E. Sharpe.

Skučiene D and Moskvina J (2015) Factors influencing the decision of whether to retire or extend one's employment. Human Affairs 26(2): 104-116.

Sonnega A, Faul JD, Ofstedal MB, Langa KM, Phillips JWR and Weir DR (2014) Cohort profile: the health and retirement study (HRS). International Journal of Epidemiology 43(2):576-585.

Swidler S and Hollans H (2010) Hedging housing risk: is it feasible? In: Smith SJ and Searle BA (eds) The Blackwell Companion to the Economics of Housing: The Housing Wealth of Nations. Chichester: Wiley-Blackwell, pp: 556-568.

Terza JV, Basu A and Rathouz PJ (2008) Two-stage residual inclusion estimation: addressing endogeneity in health econometric modelling. Journal of Health Economics 27(3): 531-543.

Toughill E, Mason DJ, Beck TL and Christopher MA (1993) Health, income, and postretirement employment of older adults. Public Health Nursing 10(2): 100107. 
Warren D (2015) Pathways to retirement in Australia: evidence from the HILDA Survey. Work, Aging and Retirement 1(2): 144-165.

Watson N, Leissou E, Guyer H and Wooden M (2019) Best practices for panel maintenance and retention. In: Johnson TP, Pennell B-E, Stoop IAL and Dorer B (eds.) Advances in Comparative Survey Methods: Multicultural, Multinational and Multiregional Contexts (3MC). New York, NY: Wiley, pp.615-639.

Watson N and Wooden M (2021) The Household, Income and Labour Dynamics in Australia (HILDA) Survey. Journal of Economics and Statistics 241(1): 131141. https://doi.org/10.1515/jbnst-2020-0029.

Wood G, Parkinson S, Searle B, Smith SJ (2013) Motivations for Equity Borrowing: A Welfare-switching Effect. Urban Studies 50(12): 2588-2607.

Yates J and Bradbury B (2010) Home ownership as a (crumbling) fourth pillar of social insurance in Australia. Journal of Housing and the Built Environment 25:193211.

Zhao B (2018) Too poor to retire? Housing prices and retirement. Review of Economic Dynamics 27: 27-47. 


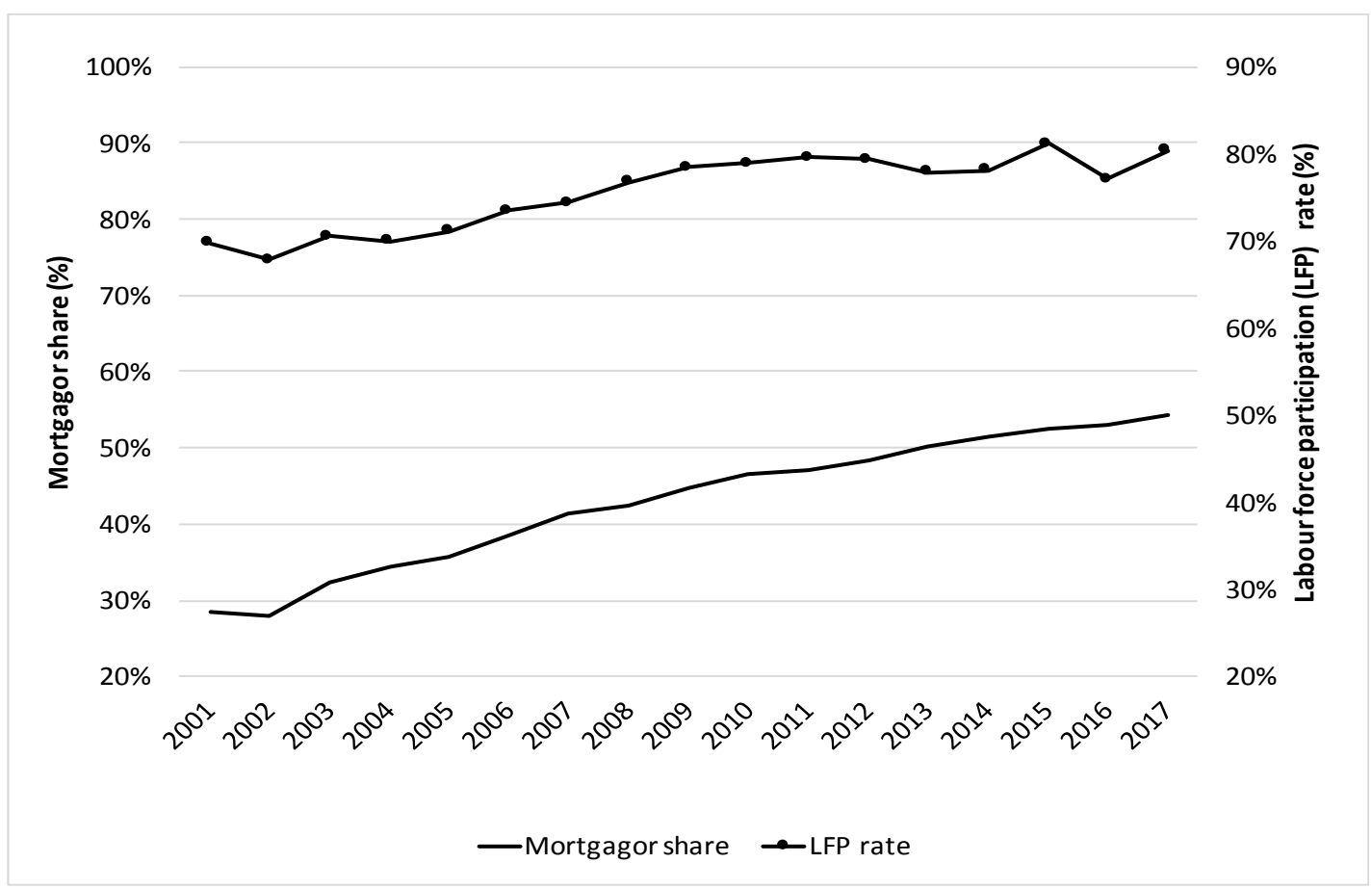

Figure 1: Mortgagor shares and labour force participation (LFP) rate of home owners aged 50-60 years in each year, 2001-2017

Source: Authors' own calculations from the 2001-2017 HILDA Survey

Note: Estimates are population-weighted using HILDA's cross-sectional population weights. 
Table 1: Duration of participation in the labour force, by sex, 2001-2017

\begin{tabular}{|l|lll|} 
Time & Risk set & Hazard rate & Survival rate \\
\hline 1 & 1,546 & 0.000 & 1.000 \\
2 & 1,487 & 0.038 & 0.995 \\
3 & 1,450 & 0.023 & 0.991 \\
4 & 1,407 & 0.028 & 0.986 \\
5 & 1,200 & 0.024 & 0.981 \\
6 & 996 & 0.047 & 0.972 \\
7 & 834 & 0.037 & 0.965 \\
8 & 686 & 0.036 & 0.957 \\
9 & 576 & 0.054 & 0.945 \\
10 & 468 & 0.068 & 0.928 \\
11 & 356 & 0.081 & 0.907 \\
12 & 270 & 0.085 & 0.885 \\
13 & 191 & 0.131 & 0.850 \\
14 & 145 & 0.145 & 0.807 \\
15 & 101 & 0.208 & 0.739 \\
16 & 64 & 0.219 & 0.657 \\
17 & 39 & 0.256 & 0.523 \\
\hline
\end{tabular}

Source: Authors' own calculations from the 2001-2017 HILDA Survey 
Table 2: Hazard model estimates of the probability of exiting the labour force for all persons aged 50-60, odds ratios

\begin{tabular}{|c|c|c|}
\hline Predictors & $\begin{array}{l}\text { Discrete-time hazard } \\
\text { model estimates }\end{array}$ & $\begin{array}{l}\text { 2SRI second stage } \\
\text { estimates }\end{array}$ \\
\hline \multirow[t]{2}{*}{$2^{\text {nd }}$ year of spell } & $0.033 * * *$ & $0.038 * * *$ \\
\hline & 0.012 & 0.014 \\
\hline \multirow[t]{2}{*}{$3^{\text {rd }}$ year of spell } & $0.024 * * *$ & $0.027 * * *$ \\
\hline & 0.008 & 0.01 \\
\hline \multirow[t]{2}{*}{$4^{\text {th }}$ year of spell } & $0.030 * * *$ & $0.035 * * *$ \\
\hline & 0.01 & 0.013 \\
\hline \multirow[t]{2}{*}{$5^{\text {th }}$ year of spell } & $0.022 * * *$ & $0.025 * * *$ \\
\hline & 0.008 & 0.01 \\
\hline \multirow{2}{*}{$6^{\text {th }}$ year of spell } & $0.041 * * *$ & $0.049 * * *$ \\
\hline & 0.014 & 0.018 \\
\hline \multirow[t]{2}{*}{$7^{\text {th }}$ year of spell } & $0.039 * * *$ & $0.045 * * *$ \\
\hline & 0.015 & 0.019 \\
\hline \multirow[t]{2}{*}{$8^{\text {th }}$ year of spell } & $0.033 * * *$ & $0.038 * * *$ \\
\hline & 0.013 & 0.017 \\
\hline \multirow[t]{2}{*}{$9^{\text {th }}$ year of spell } & $0.045 * * *$ & $0.052 * * *$ \\
\hline & 0.019 & 0.023 \\
\hline \multirow{2}{*}{$10^{\text {th }}$ year of spell } & $0.055 * * *$ & $0.058 * * *$ \\
\hline & 0.024 & 0.026 \\
\hline \multirow[t]{2}{*}{$11^{\text {th }}$ year of spell } & $0.055 * * *$ & $0.058 * * *$ \\
\hline & 0.025 & 0.028 \\
\hline \multirow[t]{2}{*}{$12^{\text {th }}$ year of spell } & $0.055 * * *$ & $0.059 * * *$ \\
\hline & 0.026 & 0.03 \\
\hline \multirow[t]{2}{*}{$13^{\text {th }}$ year of spell } & $0.076^{* * *}$ & $0.091 * * *$ \\
\hline & 0.037 & 0.046 \\
\hline \multirow[t]{2}{*}{$14^{\text {th }}$ year of spell } & $0.082 * * *$ & $0.097 * * *$ \\
\hline & 0.041 & 0.05 \\
\hline \multirow[t]{2}{*}{$15^{\text {th }}$ year of spell } & $0.096 * * *$ & $0.098 * * *$ \\
\hline & 0.049 & 0.054 \\
\hline \multirow[t]{2}{*}{$16^{\text {th }}$ year of spell } & $0.098 * * *$ & $0.112 * * *$ \\
\hline & 0.054 & 0.065 \\
\hline \multirow[t]{2}{*}{$17^{\text {th }}$ year of spell } & $0.113^{* * *}$ & $0.141 * * *$ \\
\hline & 0.067 & 0.089 \\
\hline \multirow[t]{2}{*}{ Real primary home value } & 0.989 & 0.981 \\
\hline & 0.018 & 0.023 \\
\hline \multirow[t]{2}{*}{ Real primary home debt } & $0.922 *$ & $0.910^{*}$ \\
\hline & 0.045 & 0.048 \\
\hline \multirow[t]{2}{*}{ Real other property value } & 1.016 & 1.018 \\
\hline & 0.012 & 0.013 \\
\hline Real other property debt & 0.994 & 0.993 \\
\hline & 0.046 & 0.048 \\
\hline Real superannuation wealth & $1.037 * *$ & $1.031 *$ \\
\hline & 0.018 & 0.018 \\
\hline Real non-housing non-superannuation & & \\
\hline wealth & 0.989 & 0.992 \\
\hline & 0.009 & 0.009 \\
\hline Real non-housing debt & 1.029 & 0.980 \\
\hline & 0.046 & 0.062 \\
\hline Private renter & 1.032 & 1.169 \\
\hline & 0.209 & 0.261 \\
\hline Public renter & 0.832 & 0.829 \\
\hline & 0.319 & 0.348 \\
\hline Rent-free & 1.065 & 0.635 \\
\hline & 0.465 & 0.356 \\
\hline Years till intended retirement & $0.886^{* * *}$ & $0.879 * * *$ \\
\hline & 0.01 & 0.011 \\
\hline Born 1941-1945 & $2.355 * * *$ & $2.496 * * *$ \\
\hline
\end{tabular}




\begin{tabular}{|c|c|c|}
\hline Predictors & $\begin{array}{l}\text { Discrete-time hazard } \\
\text { model estimates }\end{array}$ & $\begin{array}{l}\text { 2SRI second stage } \\
\text { estimates }\end{array}$ \\
\hline \multirow{3}{*}{ Born 1946-1955 } & 0.492 & 0.538 \\
\hline & 1.096 & 1.126 \\
\hline & 0.188 & 0.197 \\
\hline \multirow[t]{2}{*}{ De facto } & $0.682 *$ & $0.635^{*}$ \\
\hline & 0.149 & 0.148 \\
\hline \multirow[t]{2}{*}{ Separated } & 0.881 & 0.546 \\
\hline & 0.272 & 0.206 \\
\hline \multirow[t]{2}{*}{ Divorced } & 1.187 & 1.038 \\
\hline & 0.201 & 0.189 \\
\hline \multirow[t]{2}{*}{ Widowed } & 0.827 & 0.741 \\
\hline & 0.203 & 0.188 \\
\hline \multirow[t]{2}{*}{ Single never married } & 1.332 & 1.357 \\
\hline & 0.297 & 0.308 \\
\hline \multirow[t]{2}{*}{ Long-term health condition } & $2.111 * * *$ & $2.206 * * *$ \\
\hline & 0.236 & 0.255 \\
\hline \multirow[t]{2}{*}{ Informal carer } & 0.94 & 0.954 \\
\hline & 0.186 & 0.198 \\
\hline \multirow[t]{2}{*}{ Advanced diploma, diploma } & 1.24 & 1.214 \\
\hline & 0.25 & 0.248 \\
\hline \multirow[t]{2}{*}{ Cert III or IV } & $1.407 * *$ & 1.313 \\
\hline & 0.232 & 0.226 \\
\hline \multirow[t]{2}{*}{ Year 12} & $1.673 * *$ & $1.671 * *$ \\
\hline & 0.347 & 0.359 \\
\hline \multirow[t]{2}{*}{ Year 11 and below } & $1.507 * * *$ & $1.544 * * *$ \\
\hline & 0.233 & 0.249 \\
\hline \multirow[t]{2}{*}{ Employed part-time } & $1.435 * * *$ & $1.422 * * *$ \\
\hline & 0.166 & 0.169 \\
\hline \multirow[t]{2}{*}{ Unemployed } & $13.468^{* * *}$ & $12.394 * * *$ \\
\hline & 3.511 & 3.433 \\
\hline \multirow[t]{2}{*}{ Casual contract } & $1.456 * *$ & $1.499 * *$ \\
\hline & 0.227 & 0.242 \\
\hline \multirow[t]{2}{*}{ Fixed-term contract } & $1.405^{*}$ & $1.455^{*}$ \\
\hline & 0.276 & 0.293 \\
\hline \multirow[t]{2}{*}{ Labourer } & 1.288 & 1.332 \\
\hline & 0.219 & 0.235 \\
\hline \multirow[t]{2}{*}{ Replacement rate } & $1.006 * * *$ & $1.005 * *$ \\
\hline & 0.258 & 0.252 \\
\hline \multirow[t]{2}{*}{ Became eligible for Age Pension } & 1.339 & 1.332 \\
\hline & 0.417 & 0.436 \\
\hline \multirow[t]{2}{*}{ Inner Regional Australia } & $1.370 * * *$ & $1.377 * * *$ \\
\hline & 0.158 & 0.17 \\
\hline Outer Regional Australia & 0.841 & 0.9 \\
\hline & 0.15 & 0.171 \\
\hline Remote or very remote & 1.188 & 1.201 \\
\hline & 0.617 & 0.687 \\
\hline GFC & $0.603 * *$ & $0.576^{* *}$ \\
\hline & 0.148 & 0.147 \\
\hline Post-GFC & $0.538 * * *$ & $0.565 * *$ \\
\hline & 0.123 & 0.132 \\
\hline Residual & & 1.015 \\
\hline & & 0.034 \\
\hline $\mathrm{N}$ & 10,738 & 10,272 \\
\hline Wald $\mathrm{Chi}^{2}$ & $2874.88 * * *$ & $2681.65 * * *$ \\
\hline Log-likelihood & -1545.88 & -1450.55 \\
\hline
\end{tabular}

Source: Authors' own calculations from the 2001-2017 HILDA Survey

Notes: $* \mathrm{p}<0.10, * * \mathrm{p}<0.05, * * * \mathrm{p}<0.01$. Standard errors in parentheses. 
Table 3: Hazard model estimates of the probability of exiting the labour force for persons aged 50-60, by geography, birth cohort and sex, odds ratios

\begin{tabular}{|c|c|c|c|c|c|c|c|}
\hline \multirow[b]{2}{*}{ Predictors } & \multicolumn{2}{|c|}{ Geography } & \multicolumn{3}{|c|}{ Birth cohort } & \multicolumn{2}{|c|}{ Sex } \\
\hline & Urban & Regional & Born 1941-45 & Born 1946-55 & Born 1956+ & Males & Females \\
\hline & \multicolumn{7}{|c|}{ (a) All predictors included in the model } \\
\hline \multirow[t]{2}{*}{ Real primary home value } & 0.975 & 1.013 & 0.940 & 0.980 & 1.030 & 0.989 & 0.992 \\
\hline & 0.025 & 0.030 & 0.057 & 0.031 & 0.027 & 0.028 & 0.025 \\
\hline \multirow[t]{2}{*}{ Real primary home debt } & $0.885^{*}$ & 0.990 & 0.929 & 0.955 & 0.954 & $0.878^{*}$ & 0.974 \\
\hline & 0.063 & 0.070 & 0.189 & 0.069 & 0.067 & 0.069 & 0.061 \\
\hline \multirow[t]{2}{*}{ Real other property value } & 1.006 & 1.029 & 0.986 & 1.020 & 1.003 & 1.007 & 1.026 \\
\hline & 0.019 & 0.018 & 0.043 & 0.018 & 0.03 & 0.02 & 0.017 \\
\hline \multirow[t]{2}{*}{ Real other property debt } & 0.990 & 0.988 & 1.209 & 1.056 & 0.928 & 1.016 & 0.983 \\
\hline & 0.069 & 0.070 & 0.392 & 0.081 & 0.074 & 0.071 & 0.068 \\
\hline \multirow[t]{2}{*}{ Real superannuation wealth } & 1.036 & 1.022 & $1.113^{* *}$ & 0.996 & $1.061^{*}$ & 1.038 & $1.047^{*}$ \\
\hline & 0.023 & 0.031 & 0.054 & 0.027 & 0.033 & 0.026 & 0.027 \\
\hline \multirow{2}{*}{$\begin{array}{l}\text { Real non-housing non-superannuation } \\
\text { wealth }\end{array}$} & & & & & & & \\
\hline & $\begin{array}{l}0.999 \\
0.010\end{array}$ & $\begin{array}{l}0.959^{*} \\
0.021\end{array}$ & $\begin{array}{l}0.980 \\
0.022\end{array}$ & $\begin{array}{l}0.986 \\
0.013\end{array}$ & $\begin{array}{l}1.001 \\
0.017\end{array}$ & $\begin{array}{l}0.990 \\
0.017\end{array}$ & $\begin{array}{l}0.989 \\
0.011\end{array}$ \\
\hline \multirow[t]{2}{*}{ Real non-housing debt } & 1.060 & 0.880 & 0.796 & 0.913 & 1.073 & 0.982 & 1.04 \\
\hline & 0.049 & 0.132 & 0.246 & 0.143 & 0.049 & 0.108 & 0.051 \\
\hline \multirow[t]{2}{*}{ Years till intended retirement } & $0.875 * * *$ & $0.899 * * *$ & $0.915 * * *$ & $0.815^{* * *}$ & $0.936^{* * *}$ & $0.899 * * *$ & $0.885^{* * *}$ \\
\hline & 0.015 & 0.014 & 0.025 & 0.018 & 0.016 & 0.014 & 0.015 \\
\hline $\mathrm{N}$ & 6,106 & 4,632 & 775 & 4,066 & 5,728 & 5,443 & 5,295 \\
\hline Wald Chi ${ }^{2}$ & 1769.94 & 1333.07 & 248.5 & 1190.1 & 1212.2 & 1393.92 & 1585.99 \\
\hline \multirow[t]{2}{*}{ Log-likelihood } & -884.68 & -713.79 & -275.3 & -712.3 & -449.2 & -716.0 & -853.88 \\
\hline & \multicolumn{7}{|c|}{ (b) All predictors except 'years till intended retirement' included in the model } \\
\hline \multirow[t]{2}{*}{ Real primary home value } & 0.970 & 1.009 & 0.933 & 0.983 & 1.023 & 0.989 & 0.986 \\
\hline & 0.0239 & 0.03 & 0.055 & 0.027 & 0.026 & 0.027 & 0.024 \\
\hline \multirow[t]{2}{*}{ Real primary home debt } & $0.830^{*}$ & 0.938 & 0.896 & $0.847 * *$ & 0.935 & $0.818 * *$ & 0.937 \\
\hline & 0.06 & 0.071 & 0.18 & 0.069 & 0.067 & 0.066 & 0.063 \\
\hline \multirow[t]{2}{*}{ Real other property value } & 1.006 & $1.036^{*}$ & 0.991 & 1.028 & 1.011 & 1.008 & $1.035^{* *}$ \\
\hline & 0.019 & 0.018 & 0.043 & 0.018 & 0.029 & 0.02 & 0.016 \\
\hline \multirow[t]{2}{*}{ Real other property debt } & 0.957 & 0.989 & 1.211 & 1.01 & 0.928 & 1.008 & 0.97 \\
\hline & 0.0687 & 0.072 & 0.388 & 0.076 & 0.074 & 0.076 & 0.065 \\
\hline \multirow[t]{2}{*}{ Real superannuation wealth } & $1.041^{*}$ & 1.044 & $1.129 * *$ & 1.014 & $1.073 * *$ & $1.052 * *$ & $1.065^{* * *}$ \\
\hline & 0.021 & 0.03 & 0.054 & 0.024 & 0.031 & 0.024 & 0.026 \\
\hline \multirow[t]{2}{*}{$\begin{array}{l}\text { Real non-housing non-superannuation } \\
\text { wealth }\end{array}$} & 1.001 & $0.959 *$ & 0.985 & 0.991 & 0.994 & 0.992 & 0.988 \\
\hline & 0.01 & 0.22 & 0.022 & 0.013 & 0.018 & 0.017 & 0.011 \\
\hline Real non-housing debt & 1.068 & 0.828 & 0.717 & 0.862 & $1.087^{*}$ & 0.899 & 1.062 \\
\hline
\end{tabular}




\begin{tabular}{|c|c|c|c|c|c|c|c|}
\hline \multirow[b]{2}{*}{ Predictors } & \multicolumn{2}{|c|}{ Geography } & \multicolumn{3}{|c|}{ Birth cohort } & \multicolumn{2}{|c|}{ Sex } \\
\hline & Urban & Regional & Born 1941-45 & Born 1946-55 & Born 1956+ & Males & Females \\
\hline & 0.053 & 0.138 & 0.242 & 0.133 & 0.05 & 0.119 & 0.055 \\
\hline $\mathrm{N}$ & 6,106 & 4632 & 775 & 4,066 & 5,728 & 5,443 & 5,295 \\
\hline Wald Chi ${ }^{2}$ & 1769.9 & 1333.1 & 257.7 & 1435.6 & 1263.9 & 1393.9 & 1586.0 \\
\hline Log-likelihood & -884.7 & -713.8 & -282.5 & -785.8 & -458.6 & -716.0 & -853.9 \\
\hline
\end{tabular}

Source: Authors' own calculations from the 2001-2017 HILDA Survey

Notes: $* \mathrm{p}<0.10, * * \mathrm{p}<0.05, * * * \mathrm{p}<0.01$. Standard errors in parentheses. All the predictors in the 'all persons' model in table 2 have been included in the stratified models in part (a) of this table. All the predictors in the 'all persons' model with the exception of 'years till intended retirement' have been included in the stratified models in part (b) of this table. Only selected key predictors are reported. 
Table 4: Competing risks hazard model estimates of the probability of making enduring exits versus exiting with marginal attachment to the labour force for all persons aged 50-60, odds ratios

\begin{tabular}{|c|c|c|}
\hline Predictors & Enduring exit & $\begin{array}{l}\text { Exit with marginal } \\
\text { attachment }\end{array}$ \\
\hline \multirow[t]{2}{*}{$2^{\text {nd }}$ year of spell } & $0.028 * * *$ & $0.004 * * *$ \\
\hline & 0.011 & 0.004 \\
\hline \multirow[t]{2}{*}{$3^{\text {rd }}$ year of spell } & $0.023 * * *$ & $0.003 * * *$ \\
\hline & 0.009 & 0.002 \\
\hline \multirow[t]{2}{*}{$4^{\text {th }}$ year of spell } & $0.028 * * *$ & $0.004 * * *$ \\
\hline & 0.01 & 0.003 \\
\hline \multirow[t]{2}{*}{$5^{\text {th }}$ year of spell } & $0.024 * * *$ & $0.001 * * *$ \\
\hline & 0.009 & 0.001 \\
\hline \multirow[t]{2}{*}{$6^{\text {th }}$ year of spell } & $0.041 * * *$ & $0.003 * * *$ \\
\hline & 0.015 & 0.002 \\
\hline \multirow[t]{2}{*}{$7^{\text {th }}$ year of spell } & $0.032 * * *$ & $0.007 * * *$ \\
\hline & 0.014 & 0.006 \\
\hline \multirow[t]{2}{*}{$8^{\text {th }}$ year of spell } & $0.034 * * *$ & $0.002 * * *$ \\
\hline & 0.015 & 0.002 \\
\hline \multirow[t]{2}{*}{$9^{\text {th }}$ year of spell } & $0.041 * * *$ & $0.006 * * *$ \\
\hline & 0.019 & 0.006 \\
\hline \multirow[t]{2}{*}{$10^{\text {th }}$ year of spell } & $0.054 * * *$ & $0.005 * * *$ \\
\hline & 0.025 & 0.005 \\
\hline \multirow[t]{2}{*}{$11^{\text {th }}$ year of spell } & $0.057 * * *$ & $0.002 * * *$ \\
\hline & 0.028 & 0.003 \\
\hline \multirow[t]{2}{*}{$12^{\text {th }}$ year of spell } & $0.056 * * *$ & $0.004 * * *$ \\
\hline & 0.028 & 0.005 \\
\hline \multirow[t]{2}{*}{$13^{\text {th }}$ year of spell } & $0.072 * * *$ & $0.007 * * *$ \\
\hline & 0.038 & 0.009 \\
\hline \multirow[t]{2}{*}{$14^{\text {th }}$ year of spell } & $0.080 * * *$ & $0.006 * * *$ \\
\hline & 0.042 & 0.008 \\
\hline \multirow[t]{2}{*}{$15^{\text {th }}$ year of spell } & $0.081 * * *$ & $0.014 * * *$ \\
\hline & 0.045 & 0.017 \\
\hline \multirow[t]{2}{*}{$16^{\text {th }}$ year of spell } & $0.079 * * *$ & $0.016 * * *$ \\
\hline & 0.047 & 0.02 \\
\hline \multirow[t]{2}{*}{$17^{\text {th }}$ year of spell } & $0.091 * * *$ & $0.018 * * *$ \\
\hline & 0.058 & 0.025 \\
\hline \multirow[t]{2}{*}{ Real primary home value } & 0.981 & 1.031 \\
\hline & 0.020 & 0.041 \\
\hline \multirow[t]{2}{*}{ Real primary home debt } & $0.907 *$ & 0.988 \\
\hline & 0.051 & 0.099 \\
\hline \multirow[t]{2}{*}{ Real other property value } & $1.022 *$ & 0.963 \\
\hline & 0.013 & 0.046 \\
\hline Real other property debt & 0.986 & 1.064 \\
\hline & 0.050 & 0.112 \\
\hline Real superannuation wealth & $1.042 * *$ & 1.002 \\
\hline & 0.019 & 0.051 \\
\hline Real non-housing non-superannuation & & \\
\hline wealth & 0.992 & 0.970 \\
\hline & 0.009 & 0.030 \\
\hline Real non-housing debt & 0.991 & 1.100 \\
\hline & 0.061 & 0.068 \\
\hline Private renter & 0.975 & 1.232 \\
\hline & 0.216 & 0.549 \\
\hline Public renter & 0.807 & 0.747 \\
\hline & 0.339 & 0.619 \\
\hline Rent-free & 0.794 & 3.096 \\
\hline & 0.400 & 2.501 \\
\hline Years till intended retirement & $0.877 * * *$ & $0.937 * * *$ \\
\hline & 0.011 & 0.019 \\
\hline Born 1941-1945 & $2.380 * * *$ & 1.682 \\
\hline
\end{tabular}




\begin{tabular}{|c|c|c|}
\hline Predictors & Enduring exit & $\begin{array}{l}\text { Exit with marginal } \\
\text { attachment }\end{array}$ \\
\hline \multirow{3}{*}{ Born 1946-1955 } & 0.532 & 0.891 \\
\hline & 1.112 & 0.993 \\
\hline & 0.206 & 0.421 \\
\hline \multirow[t]{2}{*}{ De facto } & 0.696 & 0.696 \\
\hline & 0.163 & 0.381 \\
\hline \multirow[t]{2}{*}{ Separated } & 0.730 & 1.629 \\
\hline & 0.259 & 0.941 \\
\hline \multirow[t]{2}{*}{ Divorced } & 1.217 & 0.955 \\
\hline & 0.220 & 0.409 \\
\hline \multirow[t]{2}{*}{ Widowed } & 0.729 & 1.475 \\
\hline & 0.198 & 0.750 \\
\hline \multirow[t]{2}{*}{ Single never married } & 1.08 & $2.145^{*}$ \\
\hline & 0.278 & 0.907 \\
\hline \multirow[t]{2}{*}{ Long-term health condition } & $1.996 * * *$ & $2.275 * * *$ \\
\hline & 0.241 & 0.588 \\
\hline \multirow[t]{2}{*}{ Informal carer } & 0.936 & 1.144 \\
\hline & 0.204 & 0.484 \\
\hline \multirow[t]{2}{*}{ Advanced diploma, diploma } & 1.329 & 0.807 \\
\hline & 0.285 & 0.434 \\
\hline \multirow[t]{2}{*}{ Cert III or IV } & $1.356^{*}$ & 1.602 \\
\hline & 0.243 & 0.616 \\
\hline \multirow[t]{2}{*}{ Year 12} & $1.800 * * *$ & 1.065 \\
\hline & 0.398 & 0.575 \\
\hline \multirow[t]{2}{*}{ Year 11 and below } & $1.478 * *$ & 1.507 \\
\hline & 0.248 & 0.554 \\
\hline \multirow[t]{2}{*}{ Employed part-time } & $1.468 * * *$ & 1.187 \\
\hline & 0.182 & 0.349 \\
\hline \multirow[t]{2}{*}{ Unemployed } & $8.722 * * *$ & $18.546^{* * *}$ \\
\hline & 2.628 & 7.83 \\
\hline \multirow[t]{2}{*}{ Casual contract } & 1.244 & $2.747 * * *$ \\
\hline & 0.212 & 0.931 \\
\hline \multirow[t]{2}{*}{ Fixed-term contract } & 1.363 & 1.538 \\
\hline & 0.289 & 0.745 \\
\hline \multirow[t]{2}{*}{ Labourer } & $1.384^{*}$ & 0.792 \\
\hline & 0.249 & 0.361 \\
\hline \multirow[t]{2}{*}{ Replacement rate } & $1.599 * * *$ & 1.394 \\
\hline & 0.274 & 0.523 \\
\hline \multirow[t]{2}{*}{ Became eligible for Age Pension } & 1.307 & 1.373 \\
\hline & 0.435 & 0.946 \\
\hline \multirow[t]{2}{*}{ Inner Regional Australia } & $1.321 * *$ & 1.419 \\
\hline & 0.165 & 0.383 \\
\hline Outer Regional Australia & 0.926 & 0.402 \\
\hline & 0.173 & 0.225 \\
\hline Remote or very remote & 0.902 & 1.689 \\
\hline & 0.572 & 1.423 \\
\hline GFC & $0.642 *$ & 0.553 \\
\hline & 0.169 & 0.336 \\
\hline Post-GFC & $0.536^{* *}$ & 0.632 \\
\hline & 0.132 & 0.352 \\
\hline Residual & & 1.015 \\
\hline & & 0.034 \\
\hline $\mathrm{N}$ & 10,738 & 10,738 \\
\hline Wald $\mathrm{Chi}^{2}$ & $2691.85^{* * *}$ & $1322.97 * * *$ \\
\hline Log-likelihood & -1363.83 & -367.70 \\
\hline
\end{tabular}

Source: Authors' own calculations from the 2001-2017 HILDA Survey

Notes: $* \mathrm{p}<0.10, * * \mathrm{p}<0.05, * * * \mathrm{p}<0.01$. Standard errors in parentheses. 


\section{SUPPLEMENTARY MATERIALS}

\section{Table S1: Variable definitions and descriptives}

\begin{tabular}{|c|c|c|c|c|c|c|}
\hline $\begin{array}{l}\text { Variable } \\
\text { category }\end{array}$ & Variable & Definition & $\begin{array}{c}\text { Binary (B) } \mid \\
\text { Continuous (C) }\end{array}$ & $\begin{array}{c}\text { Current (K)| } \\
\text { Lagged (L) }\end{array}$ & $\begin{array}{c}\text { Time-varying }(\mathrm{T}) \mid \\
\text { Fixed }(\mathrm{F})\end{array}$ & Mean \\
\hline Time & $\begin{array}{l}2^{\text {nd }} \text { year of spell } \\
3^{\text {td }} \text { year of spell } \\
4^{\text {th }} \text { year of spell } \\
5^{\text {th }} \text { year of spell } \\
6^{\text {th }} \text { year of spell } \\
7^{\text {th }} \text { year of spell } \\
8^{\text {th }} \text { year of spell } \\
9^{\text {th }} \text { year of spell } \\
10^{\text {th }} \text { year of spell } \\
11^{\text {th }} \text { year of spell } \\
12^{\text {th }} \text { year of spell } \\
13^{\text {th }} \text { year of spell } \\
14^{\text {th }} \text { year of spell } \\
15^{\text {th }} \text { year of spell } \\
16^{\text {th }} \text { year of spell } \\
17^{\text {th }} \text { year of spell } \\
\end{array}$ & $\begin{array}{l}\text { Second year of LFP spell } \\
\text { Third year of LFP spell } \\
\text { Fourth year of LFP spell } \\
\text { Fifth year of LFP spell } \\
\text { Sixth year of LFP spell } \\
\text { Seventh year of LFP spell } \\
\text { Eighth year of LFP spell } \\
\text { Ninth year of LFP spell } \\
\text { Tenth year of LFP spell } \\
\text { Eleventh year of LFP spell } \\
\text { Twelfth year of LFP spell } \\
\text { Thirteenth year of LFP spell } \\
\text { Fourteenth year of LFP spell } \\
\text { Fifteenth year of LFP spell } \\
\text { Sixteenth year of LFP spell } \\
\text { Seventeenth year of LFP spell } \\
\end{array}$ & $\begin{array}{l}\mathrm{B} \\
\mathrm{B} \\
\mathrm{B} \\
\mathrm{B} \\
\mathrm{B} \\
\mathrm{B} \\
\mathrm{B} \\
\mathrm{B} \\
\mathrm{B} \\
\mathrm{B} \\
\mathrm{B} \\
\mathrm{B} \\
\mathrm{B} \\
\mathrm{B} \\
\mathrm{B} \\
\mathrm{B}\end{array}$ & $\begin{array}{l}\mathrm{K} \\
\mathrm{K} \\
\mathrm{K} \\
\mathrm{K} \\
\mathrm{K} \\
\mathrm{K} \\
\mathrm{K} \\
\mathrm{K} \\
\mathrm{K} \\
\mathrm{K} \\
\mathrm{K} \\
\mathrm{K} \\
\mathrm{K} \\
\mathrm{K} \\
\mathrm{K} \\
\mathrm{K}\end{array}$ & $\begin{array}{l}\mathrm{T} \\
\mathrm{T} \\
\mathrm{T} \\
\mathrm{T} \\
\mathrm{T} \\
\mathrm{T} \\
\mathrm{T} \\
\mathrm{T} \\
\mathrm{T} \\
\mathrm{T} \\
\mathrm{T} \\
\mathrm{T} \\
\mathrm{T} \\
\mathrm{T} \\
\mathrm{T} \\
\mathrm{T}\end{array}$ & $\begin{array}{l}0.126 \\
0.121 \\
0.118 \\
0.100 \\
0.085 \\
0.070 \\
0.058 \\
0.049 \\
0.041 \\
0.031 \\
0.024 \\
0.018 \\
0.014 \\
0.010 \\
0.006 \\
0.004 \\
\end{array}$ \\
\hline $\begin{array}{l}\text { Asset and } \\
\text { debt }\end{array}$ & $\begin{array}{l}\text { Primary home value } \\
\text { Primary home debt } \\
\text { Other property value } \\
\text { Other property debt }\end{array}$ & $\begin{array}{l}\text { Real value of the primary home in } \\
\text { A } \$ \text { '0,000s at } 2017 \text { prices, unconditional } \\
\text { mean (conditional mean) } \\
\text { Real value of the mortgage debt owed } \\
\text { against the primary home in A\$'0,000s } \\
\text { at } 2017 \text { prices, unconditional mean } \\
\text { (conditional mean) } \\
\text { Real value of property other than the } \\
\text { primary home in A } \$ \text { '0,000s at } 2017 \\
\text { prices, unconditional mean (conditional } \\
\text { mean). This variable is only available in } \\
\text { four-yearly wealth modules in HILDA. } \\
\text { Values have been linearly interpolated } \\
\text { in years with no wealth modules } \\
\text { Real value of the mortgage debt owed } \\
\text { against other property in A\$'0,000s at } \\
2017 \text { prices, unconditional mean } \\
\text { (conditional mean). This variable is }\end{array}$ & C & $\mathrm{L}$ & $\mathrm{T}$ & $\begin{array}{c}4.964 \\
(5.851) \\
0.918 \\
(1.082) \\
\\
2.040 \\
(5.635) \\
\end{array}$ \\
\hline
\end{tabular}




\begin{tabular}{|c|c|c|c|c|c|c|}
\hline $\begin{array}{l}\text { Variable } \\
\text { category }\end{array}$ & Variable & Definition & $\begin{array}{c}\text { Binary (B) | } \\
\text { Continuous (C) }\end{array}$ & $\begin{array}{c}\text { Current (K) } \mid \\
\text { Lagged (L) }\end{array}$ & $\begin{array}{l}\text { Time-varying (T) } \\
\text { Fixed }(\mathbf{F})\end{array}$ & Mean \\
\hline & $\begin{array}{l}\text { Superannuation } \\
\text { wealth } \\
\text { Non-housing non- } \\
\text { superannuation } \\
\text { wealth }\end{array}$ & $\begin{array}{l}\text { only available in four-yearly wealth } \\
\text { modules in HILDA. Values have been } \\
\text { linearly interpolated in years with no } \\
\text { wealth modules } \\
\text { Real value of superannuation balance in } \\
\text { A \$'0,000s at } 2017 \text { prices. This variable } \\
\text { is only available in four-yearly wealth } \\
\text { modules in HILDA. Values have been } \\
\text { linearly interpolated in years with no } \\
\text { wealth modules } \\
\text { Real value of all assets other than the } \\
\text { primary home, other property and } \\
\text { superannuation in A \$'0,000s at } 2017 \\
\text { prices. This variable is only available in } \\
\text { four-yearly wealth modules in HILDA. } \\
\text { Values have been linearly interpolated } \\
\text { in years with no wealth modules } \\
\text { Real value of all debt other than debt } \\
\text { owed against primary home and other } \\
\text { property in A } \$ 0,000 \text { s at } 2017 \text { prices. } \\
\text { This variable is only available in four- } \\
\text { yearly wealth modules in HILDA. } \\
\text { Values have been linearly interpolated } \\
\text { in years with no wealth modules }\end{array}$ & C & $\mathrm{L}$ & $\mathrm{T}$ & 2.921 \\
\hline $\begin{array}{l}\text { Housing } \\
\text { tenure }\end{array}$ & $\begin{array}{l}\text { Home owner (ref) } \\
\text { Private renter } \\
\text { Public renter } \\
\text { Rent-free }\end{array}$ & $\begin{array}{l}1 \text { if home owner, } 0 \text { otherwise } \\
1 \text { if private renter, } 0 \text { otherwise } \\
1 \text { if public renter, } 0 \text { otherwise } \\
1 \text { if rent-free, } 0 \text { otherwise }\end{array}$ & $\begin{array}{l}\text { B } \\
\text { B } \\
\text { B } \\
\text { B }\end{array}$ & $\begin{array}{l}\mathrm{L} \\
\mathrm{L} \\
\mathrm{L} \\
\mathrm{L}\end{array}$ & $\begin{array}{l}\mathrm{T} \\
\mathrm{T} \\
\mathrm{T} \\
\mathrm{T}\end{array}$ & $\begin{array}{l}0.848 \\
0.118 \\
0.015 \\
0.014\end{array}$ \\
\hline $\begin{array}{l}\text { Retirement } \\
\text { plans }\end{array}$ & $\begin{array}{l}\text { Years till intended } \\
\text { retirement }\end{array}$ & $\begin{array}{l}\text { Age of intended retirement minus actual } \\
\text { age }\end{array}$ & $\mathrm{C}$ & $\mathrm{K}$ & $\mathrm{T}$ & 10.729 \\
\hline Birth cohort & $\begin{array}{l}\text { Born 1941-1945 } \\
\text { (silent generation) } \\
\text { Born 1946-1955 } \\
\text { ('older' baby } \\
\text { boomers) }\end{array}$ & $\begin{array}{l}1 \text { if born 1941-1945, } 0 \text { otherwise } \\
1 \text { if born 1946-1955, } 0 \text { otherwise }\end{array}$ & B & $\begin{array}{l}\mathrm{K} \\
\mathrm{K}\end{array}$ & $\begin{array}{l}\mathrm{F} \\
\mathrm{F}\end{array}$ & $\begin{array}{l}0.074 \\
0.363\end{array}$ \\
\hline
\end{tabular}




\begin{tabular}{|c|c|c|c|c|c|c|}
\hline $\begin{array}{l}\text { Variable } \\
\text { category }\end{array}$ & Variable & Definition & $\begin{array}{c}\text { Binary (B) | } \\
\text { Continuous (C) }\end{array}$ & $\begin{array}{c}\text { Current (K) } \mid \\
\text { Lagged (L) }\end{array}$ & $\begin{array}{c}\text { Time-varying (T) } \\
\text { Fixed (F) } \\
\end{array}$ & Mean \\
\hline & $\begin{array}{l}\text { Born 1956+ } \\
\text { ('younger' baby } \\
\text { boomers) (ref) }\end{array}$ & 1 if born 1956 or later, 0 otherwise & $\mathrm{B}$ & $\mathrm{K}$ & $\mathrm{F}$ & 0.556 \\
\hline $\begin{array}{l}\text { Marital } \\
\text { status }\end{array}$ & $\begin{array}{l}\text { Married (ref) } \\
\text { De facto } \\
\text { Separated } \\
\text { Divorced } \\
\text { Widowed } \\
\text { Single never married }\end{array}$ & $\begin{array}{l}1 \text { if legally married, } 0 \text { otherwise } \\
\text { If de facto, } 0 \text { otherwise } \\
1 \text { if separated, } 0 \text { otherwise } \\
1 \text { if divorced, } 0 \text { otherwise } \\
1 \text { if widowed, } 0 \text { otherwise } \\
1 \text { if single never married, } 0 \text { otherwise }\end{array}$ & $\begin{array}{l}\text { B } \\
\text { B } \\
\text { B } \\
\text { B } \\
\text { B } \\
\text { B }\end{array}$ & $\begin{array}{l}\text { L } \\
\text { L } \\
\text { L } \\
\text { L } \\
\text { L } \\
\text { L }\end{array}$ & $\begin{array}{l}\mathrm{T} \\
\mathrm{T} \\
\mathrm{T} \\
\mathrm{T} \\
\mathrm{T} \\
\mathrm{T}\end{array}$ & $\begin{array}{l}0.654 \\
0.095 \\
0.039 \\
0.115 \\
0.032 \\
0.065\end{array}$ \\
\hline $\begin{array}{l}\text { Health and } \\
\text { care }\end{array}$ & $\begin{array}{l}\text { Long-term health } \\
\text { condition } \\
\text { Informal carer status }\end{array}$ & $\begin{array}{l}1 \text { if suffering from a long-term health } \\
\text { condition or disability, } 0 \text { otherwise } \\
1 \text { if caring for a spouse or elderly } \\
\text { relative for } 10+\text { hours per week or if } \\
\text { receiving Carer Payment, } 0 \text { otherwise }\end{array}$ & $\begin{array}{l}\text { B } \\
\text { B }\end{array}$ & $\begin{array}{l}\mathrm{L} \\
\mathrm{L}\end{array}$ & $\begin{array}{l}\mathrm{T} \\
\mathrm{T}\end{array}$ & $\begin{array}{l}0.179 \\
0.066\end{array}$ \\
\hline $\begin{array}{l}\text { Highest } \\
\text { qualification }\end{array}$ & $\begin{array}{l}\text { University degree } \\
\text { (ref) } \\
\text { Advanced diploma, } \\
\text { diploma } \\
\text { Cert III or IV } \\
\text { Year } 12 \\
\text { Year } 11 \text { or below }\end{array}$ & $\begin{array}{l}1 \text { if highest qualification is a university } \\
\text { degree, } 0 \text { otherwise } \\
1 \text { if highest qualification is an advanced } \\
\text { diploma or diploma, } 0 \text { otherwise } \\
1 \text { if highest qualification is a certificate } \\
\text { III or IV, } 0 \text { otherwise } \\
1 \text { if highest qualification is Year 12, } 0 \\
\text { otherwise } \\
1 \text { if highest qualification is Year 11, } 0 \\
\text { otherwise }\end{array}$ & $\begin{array}{l}\mathrm{B} \\
\mathrm{B} \\
\mathrm{B} \\
\mathrm{B} \\
\mathrm{B}\end{array}$ & $\begin{array}{l}\mathrm{L} \\
\mathrm{L} \\
\mathrm{L} \\
\mathrm{L} \\
\mathrm{L}\end{array}$ & $\begin{array}{l}\mathrm{T} \\
\mathrm{T} \\
\mathrm{T} \\
\mathrm{T} \\
\mathrm{T}\end{array}$ & $\begin{array}{l}0.293 \\
0.106 \\
0.249 \\
0.086 \\
0.266\end{array}$ \\
\hline $\begin{array}{l}\text { Work } \\
\text { attributes }\end{array}$ & $\begin{array}{l}\text { Employed full-time } \\
\text { (ref) } \\
\text { Employed part-time } \\
\text { Unemployed } \\
\text { Permanent contract } \\
\text { (ref) } \\
\text { Fixed-term contract } \\
\\
\text { Casual contract } \\
\text { Labourer }\end{array}$ & $\begin{array}{l}1 \text { if employed full-time, } 0 \text { otherwise } \\
1 \text { if employed part-time, } 0 \text { otherwise } \\
1 \text { if unemployed, } 0 \text { otherwise } \\
1 \text { if on permanent job contract, } 0 \\
\text { otherwise } \\
1 \text { if on fixed-term job contract, } 0 \\
\text { otherwise } \\
1 \text { if on casual job contract, } 0 \text { otherwise } \\
1 \text { if occupation is labourer, } 0 \text { otherwise }\end{array}$ & $\begin{array}{l}\text { B } \\
\text { B } \\
\text { B } \\
\text { B } \\
\text { B } \\
\text { B } \\
\text { B }\end{array}$ & $\begin{array}{l}\text { L } \\
\text { L } \\
\text { L } \\
\text { L } \\
\text { L } \\
\text { L } \\
\text { L }\end{array}$ & $\begin{array}{l}\mathrm{T} \\
\mathrm{T} \\
\mathrm{T} \\
\mathrm{T} \\
\mathrm{T}\end{array}$ & $\begin{array}{l}0.689 \\
0.261 \\
0.011 \\
0.649\end{array}$ \\
\hline
\end{tabular}




\begin{tabular}{|c|c|c|c|c|c|c|}
\hline $\begin{array}{l}\text { Variable } \\
\text { category }\end{array}$ & Variable & Definition & $\begin{array}{c}\text { Binary (B) | } \\
\text { Continuous (C) }\end{array}$ & $\begin{array}{c}\text { Current (K) | } \\
\text { Lagged (L) }\end{array}$ & $\begin{array}{l}\text { Time-varying (T) } \mid \\
\text { Fixed (F) } \\
\end{array}$ & Mean \\
\hline $\begin{array}{l}\text { Work } \\
\text { incentives }\end{array}$ & $\begin{array}{l}\text { Replacement rate } \\
\text { Became eligible for } \\
\text { Age Pension }\end{array}$ & $\begin{array}{l}\text { Household disposable income while } \\
\text { NILF / household disposable income } \\
\text { while in the labour force } \\
1 \text { if became eligible for Age Pension for } \\
\text { the first time, } 0 \text { otherwise }\end{array}$ & $\mathrm{C}$ & $\mathrm{L}$ & $\mathrm{T}$ & 0.011 \\
\hline Region & $\begin{array}{l}\text { Major city (ref) } \\
\text { Inner regional } \\
\text { Outer regional } \\
\text { Remote or very } \\
\text { remote }\end{array}$ & $\begin{array}{l}1 \text { if residing in a major city, } 0 \text { otherwise } \\
1 \text { if residing in an inner regional area, } 0 \\
\text { otherwise } \\
1 \text { if residing in an outer regional area, } 0 \\
\text { otherwise } \\
1 \text { if residing in a remote or very remote } \\
\text { area, } 0 \text { otherwise }\end{array}$ & $\begin{array}{l}\text { B } \\
\text { B } \\
\text { B } \\
\text { B }\end{array}$ & $\begin{array}{l}\mathrm{K} \\
\mathrm{K} \\
\mathrm{K} \\
\mathrm{K}\end{array}$ & $\begin{array}{l}\mathrm{T} \\
\mathrm{T} \\
\mathrm{T} \\
\mathrm{T}\end{array}$ & $\begin{array}{l}0.623 \\
0.262 \\
0.105 \\
0.010\end{array}$ \\
\hline $\begin{array}{l}\text { Economic } \\
\text { cycle }\end{array}$ & $\begin{array}{l}\text { Pre-GFC (ref) } \\
\text { GFC } \\
\text { Post-GFC }\end{array}$ & $\begin{array}{l}1 \text { if observation is from 2001-2006, } 0 \\
\text { otherwise } \\
1 \text { if observation is from 2007-2008, } 0 \\
\text { otherwise } \\
1 \text { if observation is from 2009-2017, } 0 \\
\text { otherwise }\end{array}$ & $\begin{array}{l}\mathrm{B} \\
\mathrm{B} \\
\mathrm{B}\end{array}$ & $\begin{array}{l}\mathrm{K} \\
\mathrm{K} \\
\mathrm{K}\end{array}$ & $\begin{array}{l}\mathrm{T} \\
\mathrm{T} \\
\mathrm{T}\end{array}$ & $\begin{array}{l}0.185 \\
0.090 \\
0.725\end{array}$ \\
\hline
\end{tabular}

